\title{
ІВАН ГОРБАЧЕВСЬКИЙ - УКРАЇНСЬКИЙ ВЧЕНИЙ СВІТОВОЇ СЛАВИ
}

\author{
Ю. І. Бондаренко, Я. І. Гонський, О. В. Лотоцька \\ ДВНЗ “Тернопільський державний медичний університет імені І. Я. Горбачевського МОЗ Украйни”
}

\section{IVAN HORBACHEVSKY - UKRAINIAN WORLD SCIENTIST OF FAME}

\author{
Yu. I. Bondarenko, Ya. I. Honskyy, O. V. Lototska \\ SHEI "Ternopil State Medical University by I. Ya. Horbachevsky of MPH of Ukraine"
}

\begin{abstract}
У статті розповідається про видатного вченого та відомого громадського діяча Івана Яковича Горбачевського, автора понад 60-ти наукових праць, понад 100 наукових розробок у галузі санітарії та багатьох наукових відкриттів. Усе своє життя він присвятив вивченню хімічного складу та хімічних процесів в організмі здорової та хворої людини, з'ясуванню причин та опрацюванню способів лікування багатьох недуг.
\end{abstract}

The article tells about the famous and well-known public figure Ivan Yakovych Horbachevsky, author of over 60 scientific publications and more than 100 scientific developments in the field of sanitation and many scientific discoveries. All his life he devoted to the study of the chemical composition and chemical processes in healthy and sick person, ascertain the cause and working methods of treating many ailments.

Вступ. 15 травня 2014 р. виповнюється 160 років від дня народження Івана Яковича Горбачевського геніального вченого та відомого громадського діяча, який справедливо належить до когорти найвидатніших учених кінця XIX - першої половини XX століття. Враховуючи всі його заслуги, 2004 рік ЮНЕСКО визнало роком академіка Івана Горбачевського у зв'язку з 150-річчям від дня його народження.

Так сталося, що I. Горбачевського добре знали, шанували та відзначали його ювілеї при житті та після смерті в Європі. Але майже не згадували і не знали на Батьківщині за часів Радянського Союзу. Хоча перебуваючи поза межами України, він постійно працював і жив для України, для ії звеличення, піднесення ії культури, освіти, здобуття незалежності.

Основна частина. Про світовий авторитет і популярність І. Горбачевського говорять ті чисельні наукові та урядові титули, звання та нагороди, яких він був удостоєний. Досить перерахувати тільки самі титули, якими володів І. Я. Горбачевський, щоб зрозуміти, що це непересічна особистість: доктор медичних наук, професор, чотириразовий декан медичного факультету Карлового університету в Празі, а згодом його ректор, член Крайової ради здоров'я Чеського королівства і Вищої санітарної ради Австрії, довічний член Палати панів австрійського парламенту, дійсний таємний радник, член Ради з технічних досліджень у Відні. В 1917-1918 рр. Іван Горбачевський очолював Міністерство здоров'я Австрії, був

() Ю. І. Бондаренко, Я. І. Гонський, О. В. Лотоцька його першим міністром. Став одним із ініціаторів створення Українського вільного університету у Відні й Празі, де працював спочатку професором, завідувачем кафедри, а пізніше - ректором цього навчального закладу. Дійсний член Всеукраїнської академії наук, дійсний і почесний член Наукового товариства ім. Шевченка, голова управи товариства "Музей визвольної боротьби України" в Празі, почесний голова Комітету оборони Карпатської України, перший почесний голова Спілки українських лікарів у ЧехоСловаччині, почесний член Чеської королівської академії наук, лікарських товариств: Вільнюса, Кракова, Відня.

На противагу багатьом українцям він, проживши багато років (понад 60) за межами України, не порвав з нею зв'язків, не відрікся рідної мови, постійно відчував себе сином Української Землі і докладав всі свої зусилля для возвеличення та визволення свого народу. Тому дивно, що в Україні за часів тоталітаризму про Івана Горбачевського знало лише вузьке коло людей, головно - спеціалістів у галузі біохімії. Водночас його знали, шанували і високо цінували в Австрії, Чехії, Німеччині, Франції, Польщі.

Та все-таки І. Горбачевський залишився до останніх днів свого життя українцем. Ідею служити своєму народові він усмоктав із молоком матері, разом 3 iї піснями та мудрими порадами батька-священика. Закладені в дитячі роки зерна національної свідомості проросли буйним цвітом у час навчання у Віденському університеті: в студентському об'єднанні “Січ”, яке він очолив, створив українську бібліотеку, видав 
“Історію України” Маркевича, книжечки поезій Т. Шевченка. За цю діяльність І. Горбачевський потрапив під нагляд поліції у Відні. Він постійно працював на українську національну справу: зорганізовував і проводив українські наукові з’ізди в Празі, видав українською мовою перший університетський підручник $з$ органічної хімії, опрацював наукову хімічну термінологію, боровся за відкриття Українського університету у Львові, створив фонд допомоги незаможним студентам, відкрив і очолив музей Визвольної боротьби України, зорганізував фонд допомоги Карпатській незалежній Україні.

Іван Горбачевський прожив на світі 88 років, з них 67 - за межами України. Але з Україною був тісно пов'язаний, жив іiї радощами та болями, багато робив для визволення ії від іноземного панування.

Народився Іван Горбачевський у Галичині, недалеко від Тернополя, в с. Зарубинці 15 травня 1854 року. Закінчивши в м. Збаражі народну школу, продовжив навчатися в класичній гімназії м. Тернополя. Тут він став членом таємного гуртка української учнівської молоді "Громада", де здобув першооснови української національної свідомості. Громадівці читали і вивчали твори І. Котляревського, Т. Шевченка, П. Куліша. За мету обрали - будити в народі національну свідомість, що мало неабияке значення, враховуючи польсько-німецьке оточення викладацького складу в гімназії та засилля москвофільства серед тогочасної нечисленної інтелігенції Галичини. Після закінчення гімназії Іван обирає професію лікаря, тому подальша його життєва стежка потяглася до Віденського університету на медичний факультет (в Галичині вищих медичних студій не було). Ще будучи студентом, він виявив схильність та великі здібності до наукової праці й цим зацікавив своїх професорів.

На II курсі університету І. Горбачевський виконав і надрукував першу свою наукову працю "Про вестибулярний нерв”, за яку був відзначений керівництвом університету і зарахований до наукового німецького товариства. Німці побачили в молодому студентові майбутню перспективу і не помилилися. Наступні студії, дослідження і публікації були переважно пов’ язані з органічною, біологічною та лікарською хіміями. Більшу частину життя Іван Якович присвятив вивченню хімічного складу та хімічних процесів в організмі здорової та хворої людини, з’ясуванню причин та опрацюванню способів лікування багатьох недуг.

Перша наукова праця, яка принесла йому наукове визнання та світову славу, - це “Синтез сечової кислоти”. Вона викликала наукову сенсацію, здивування та захоплення. Вперше у світі молодий 28-літній українець, випускник Віденського університету Іван Горбачевський синтезував сечову кислоту. Праця була надрукована в німецьких, австрійських i польських часописах. Сечова кислота була відома ще в XVII ст. як така, що входить до складу сечових камінців та сечі. Але синтезувати ії̈ штучно не вдавалося нікому, хоча над цим питанням працювали всесвітньо відомі науковці, зокрема Е. Фішер, В. Траубе, О. Розен та ін.

Через рік його запросили до Празького університету на посаду професора медичного факультету, а 1884 р. - обрали професором лікарської хімії з одночасним викладанням фармакології. Усі наступні праці (наукові, педагогічні, видавничі, громадсько-політичні) Івана Яковича були пов'язані з чеським Карловим університетом у Празі. Цьому університетові він віддав 37 років життя. Упродовж 35 років (1883-1917 рр.) був професором кафедри лікарської хімії Карлового університету в Празі. В 1902-1903 рр. - ректор Карлового університету; чотириразовий декан медичного факультету в 1889-1890, 1894-1895, 1904-1905, 1911-1912 роках.

У Празі він проводив дослідження з гігієни, загальної хімії, епідеміології, судової медицини, токсикології. I. Горбачевський написав і видрукував чеською мовою перший університетський підручник з лікарської хімії в 4-х томах (неорганічна, органічна та біологічна хімія). Він навчав та виростив велику когорту лікарів і науковців.

У наступні роки він запропонував і ще інші способи синтезу сечової кислоти, синтезував біологічно важливу речовину креатин; довів, що амінокислоти є будівельним матеріалом для білків, відкрив фермент ксантиноксидазу, який бере участь в утворенні сечової кислоти в організмі. Велика заслуга І. Горбачевського перед наукою і в тому, що вперше (1899 р.) встановив джерела сечової кислоти в організмі людини.

Варто зазначити, що опрацьовуючи теорію утворення сечової кислоти, професор одночасно розробив методику виділення нуклеїнових кислот із тканин організму. Значення праць Горбачевського з перетворення нуклеїнових кислот до кінцевих продуктів можна належно оцінити з точки зору регуляції синтезу і розщеплення нуклеїнових кислот, що інтенсивно опрацьовується в наш час і поглиблює наші уявлення про суть життя на молекулярному рівні. Праці професора І. Горбачевського з вивчення утворення сечової кислоти в організмі дають ключ для розуміння патогенезу подагри та ії лікування.

Його наукова спадщина - це вагомий внесок до української, чеської, а зрештою - світової науки. 
I. Горбачевський - автор понад 60-ти наукових праць, понад 100 наукових розробок у галузі санітарії та багатьох наукових відкриттів. Один із фундаторів української хімічної термінології на народній основі. Світова наука в галузі лікарської хімії ще й донині живе ідеями геніального українського вченого, а багато проблем, поставлених ним, ще чекають вирішення.

В 1917-1918 pp. І. Горбачевський стає засновником міністерства і першим міністром здоров'я АвстроУгорщини. За проектом розбудови і програми дії цього міністерства пізніше розбудувалися міністерства здоров'я Англії, Франції та інших держав.

\section{Література}

1. Бабюк Я. Академік АН УРСР Іван Горбачевський / Я. Бабюк // Український біохімічний журнал. - 1962. Т. 34, №4. - С. 633-635.

2. Савицький І. В. Основи біохімії/ І. В. Савицький. -Київ : Вища школа, 1965. -С. 245-246.

3. Головацький I. Академік Горбачевський / І. Головацький// Україна і світ. - 1994. -С. 9-10.
За своє життя Іван Горбачевський практично не хворів. Помер він 24 травня 1942 року після короткочасної хвороби. Похований на малому цвинтарі Святого Матея у Шарці під Прагою.

Висновки. Ім'я академіка Івана Горбачевського є символом і взірцем науковця, патріота, який все своє життя віддав служінню науці та рідному народові. На життєвому і творчому шляху Горбачевського будуть вчитися сучасні і прийдешні покоління українців відданості своїй Батьківщині, незалежно від того, де вони перебуватимуть.

4. Гонський Я. І. Академік І. Горбачевський і 60 років 3 часу смерті та 120 років від часу синтезу сечової кислоти / Я. І. Гонський, Ю. І. Губський // Медична хімія. - 2002. №4.-С.96-97.

5. Гонський Я. Іван Горбачевський у спогадах і листуваннях / Я. Гонський. - Тернопіль : Укрмедкнига, 2004. - 183 с.

6. Гонський Я. Брати Горбачевські / Я. Гонський. - Тернопіль : Укрмедкнига, 2009. - 139 с. 